\title{
Przewalski's horse-adaptation to semi-wild life in desert conditions
}

\author{
O. B. Pereladova, A. J. Sempéré, N. V. Soldatova, V. U. Dutov, G. Fisenko and V. E. Flint
}

\begin{abstract}
In 1989 an experiment was started at the Bukhara Breeding Centre, Kyzylkum Desert, Uzbekistan, to discover whether zoo-bred Przewalski's horses Equus przewalskii could adapt to semi-wild desert conditions. One stallion and four mares of different ages were released into a 5126-ha fenced area and monitored over a period of 17 years. This paper presents the information gained from the studies concerning home ranges, interactions with other ungulate species, adaptation to new food
\end{abstract}

resources and comparative changes in daily activity. The results of breeding and changes in the structure of the group are also presented. The horses appeared to adapt well to the new conditions and there appeared to be no negative effects of interspecific interaction with introduced kulans Equus hemionus kulan in the release area.

Keywords Adaptations, ecology, Przewalski's horse, reintroduction.

\section{Introduction}

Przewalski's horse Equus przewalskii was last recorded in the wild in 1968, in Mongolia (Ryder, 1988). While more than 1000 individuals have been bred in captivity in zoos and specialized breeding centres in Europe and North America (P. Duncan, pers. comm.), there are problems associated with long-term captive breeding of a species. Maintenance in artificial conditions accompanied by inbreeding can lead to a loss of genetic variability, development of genetic diseases, loss of seasonal reproduction, declines in fertility, increase in the mortality of young animals and other negative consequences (see Bouman \& Bos, 1979; Volf, 1981; Bouman \& Bouman, 1988; Miller, 1988; Nouls, 1988; Ryder, 1988). The urgency of establishing a free-ranging, self-propagating population in the wild was noted in 1985, at a conference in Moscow sponsored by FAO and UNEP, and at an international symposium on Przewalski's horse in Leipzig in 1990. The recommen-

O. B. Pereladova (corresponding author) and V. E. Flint All-Russia Research Institute of Nature Conservation, Sadki-Znamenskoye, Vilar, Moscow 113628, Russia. Address for correspondence: CNRS, 14 Goubkina str., App. 109, Moscow 117312, Russia.

E-mail: olga@perelad.msk.ru

A. J. Sempéré Centre d'Etudes Biologiques de Chizé, CNRS F-79360, Villier en Bois, France. E-mail: sempere@glasnet.ru

N. V. Soldatova and V. U. Dutov Ecocenter 'Goitred gazelle', Bukhara, Cagan 705014, Uzbekistan.

G. Fisenko Faculty of Biology, Moscow State University, Moscow, Russia.

Received 23 March 1998. Accepted 21 July 1998 dations of these meetings were included in the action plan for the conservation of wild equids (Duncan, 1992a).

The main problems to be overcome in establishing a wild population were identifying a suitable area and selecting appropriate sources of animals. Other factors that needed to be taken into account were the ability of zoo-bred animals to adapt to conditions in the wild and the consequences of interspecific interaction with other species of ungulates in the release area. This paper describes an experiment to investigate the adaptability of zoo-bred Przewalski's horses to desert conditions and their ability to survive on desert plants as the only source of food.

\section{Bukhara Breeding Centre-the release area}

The experiment took place at the Bukhara Breeding Centre in the Kyzylkum Desert, Uzbekistan $\left(40^{\circ} \mathrm{N}\right.$, $65^{\circ} \mathrm{E}$ ), which was established in 1978 (Fig. 1). It consists of a fenced 5126-ha area of desert, which contains a system of lakes connected by canals. The mineral content of the lake water varies between 2 and $75 \mathrm{~g} / \mathrm{L}$. Some lakes are relatively stable in their mineral content (freshwater lakes) and these have relatively low mineral concentrations $(2-5 \mathrm{~g} / \mathrm{L})$. Others vary considerably, with the mineral concentration depending on the supply of groundwater and evaporation. Animal pens and a laboratory are situated in the southern part of the area.

Rainfall is less than $125 \mathrm{~mm} /$ year and the temperature ranges from a maximum of $40-46^{\circ} \mathrm{C}$ in June and July to a minimum of -8 to $-25^{\circ} \mathrm{C}$ in December and January. The typical desert vegetation contains few 


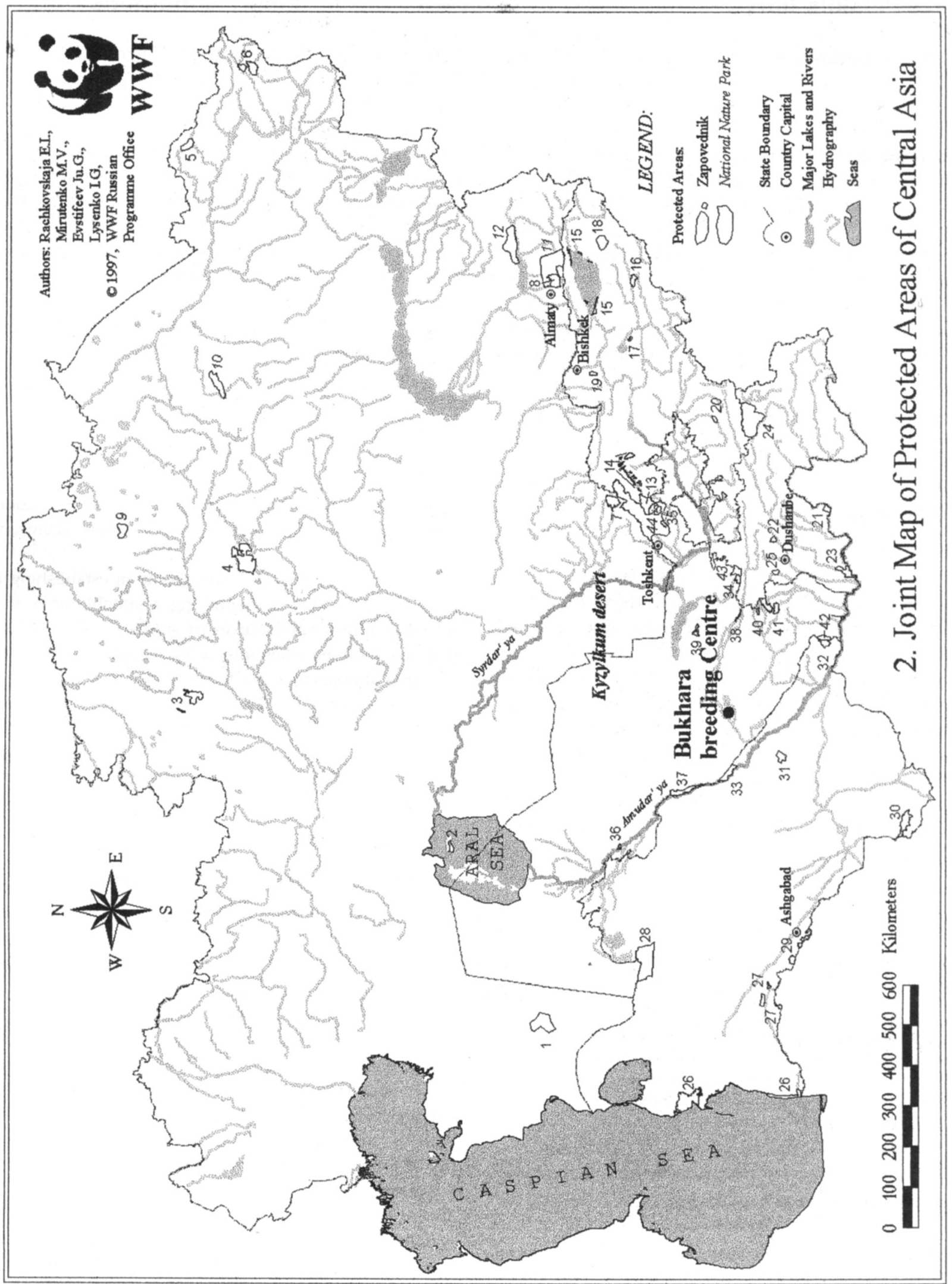


Table 1 Composition of groups of Przewalski's horses at the Bukhara Breeding Centre

\begin{tabular}{|c|c|c|c|c|c|}
\hline Origin of horses & $\begin{array}{l}\text { International name } \\
\text { and sex }\end{array}$ & $\begin{array}{l}\text { No. in international } \\
\text { stud book of birth }\end{array}$ & Date & Presence in Centre & $\begin{array}{l}\text { Parents } \\
\text { male }+ \text { female }\end{array}$ \\
\hline Moscow Zoo & M10, male & 1152 & $16 / 6 / 83$ & $24 / 4 / 87$ (died $11 / 88)$ & \\
\hline Moscow Zoo & M19, male & 1561 & $8 / 5 / 87$ & $30 / 10 / 89$ & \\
\hline Moscow Zoo & M17, female & 1445 (Verba) & $25 / 5 / 86$ & $30 / 10 / 89$ & \\
\hline Leningrad Zoo & L11, male & 1517 & $28 / 10 / 86$ & $30 / 11 / 90($ died $9 / 95)$ & \\
\hline Moscow Zoo & M26, female & 1834 (Vip) & $5 / 5 / 89$ & $30 / 11 / 90$ & \\
\hline Leningrad Zoo & L5, female & 1030 (Gerda) & $12 / 4 / 82$ & $30 / 11 / 90$ & \\
\hline Leningrad Zoo & L58, female & 901 (Vesnitsa) & $24 / 5 / 80$ & $30 / 11 / 90$ & \\
\hline Bukhara & B1, unknown & 一 & $30 / 1 / 92$ & Died $30 / 1 / 92$ & $\mathrm{M} 19+\mathrm{M} 17$ \\
\hline Bukhara & $\mathrm{B} 2$, male & - & $23 / 4 / 92$ & Died $27 / 5 / 93$ & $\mathrm{~L} 11+\mathrm{M} 26$ \\
\hline Bukhara & B3, female & - & $17 / 5 / 92$ & $\begin{array}{l}\text { Escaped from Centre, } \\
6 / 94\end{array}$ & $\mathrm{M} 19+\mathrm{L} 5$ \\
\hline Bukhara & B4, unknown & - & $12 / 6 / 92$ & Died $17 / 6 / 92$ & $\mathrm{~L} 11+\mathrm{L} 58$ \\
\hline Bukhara & B5, male & 555 , yellow & $3 / 4 / 94$ & Died 11/95 & $\mathrm{M} 19+\mathrm{M} 17$ \\
\hline Bukhara & B6, male & 014 , green & $7 / 5 / 94$ & $7 / 5 / 94$ & $\mathrm{M} 19+\mathrm{M} 26$ \\
\hline Bukhara & B7, male & 037, pink & $29 / 5 / 94$ & $29 / 5 / 94$ & $\mathrm{M} 19+\mathrm{L} 58$ \\
\hline Bukhara & B8, male & - & $3 / 5 / 95$ & Died 5/5/95 & $\mathrm{M} 19+\mathrm{L} 5$ \\
\hline Bukhara & B9. Male & - & $15 / 5 / 95$ & $15 / 5 / 95$ & $\mathrm{M} 19+\mathrm{M} 26$ \\
\hline Bukhara & B10, male & Branded ' $00^{\prime}$ & $3 / 7 / 95$ & $3 / 7 / 95$ & $\mathrm{M} 19+\mathrm{M} 17$ \\
\hline Bukahara & B11, female & - & $30 / 5 / 95$ & $30 / 5 / 95$ & $\mathrm{M} 19+\mathrm{L} 58$ \\
\hline Bukhara & B12, female & Vetka & $28 / 7 / 96$ & $28 / 7 / 96$ & $\mathrm{M} 19+\mathrm{M} 26$ \\
\hline Bukhara & B13, male & 一 & $30 / 4 / 97$ & $30 / 497$ & $\mathrm{M} 19+\mathrm{M} 26$ \\
\hline Bukhara & B14, female & - & $5-6 / 6 / 97$ & $6 / 6 / 97$ & $\mathrm{M} 19+\mathrm{M} 17$ \\
\hline Bukhara & B15, male & - & $10 / 7 / 97$ & $10 / 7 / 97$ & $\mathrm{M} 19+\mathrm{L} 58$ \\
\hline
\end{tabular}

grass species (Shenbrot, 1987; Mordonov, 1993) and vegetation cover ranges from 5 to 75 per cent.

\section{Introduction techniques}

In 1979-80 groups of goitred gazelles Gazella subgutturosa and kulans Equus hemionus kulan were introduced into the release area. In the period 1992-96 gazelle numbers fluctuated between 600 and 800 (Pereladova et al., 1998), and kulan numbers between 20 and 35. The kulans originated from a group of one male and three females, which have been breeding successfully since 1979. Their numbers have been artificially regulated since 1990 to avoid competition with the gazelles.

Between April 1987 and December 1990 seven Przewalski's horses were brought to Bukhara, four from Moscow Zoo and three from Leningrad Zoo (Table 1). The first horse to be brought to the Centre, M10 (a male), lived there for c. 18 months and its adaptations to the new conditions were studied (Flint et al., 1991). However, when it died in November 1988, a postmortem examination revealed that it had only one developed kidney, which was in poor condition, and some other genetic disorders. One of these, a distortion of the nasal partition, prevented the horse from dislodging gadfly larvae from the nasal tract, and this caused respiratory problems.
After quarantine, the other six horses were divided into two groups, each consisting of one male and two females: one group-L11 (male), M26 (female) and L58 (female) - were kept in a 6-ha pen; the other groupM19 (male), M17 (female) and L5 (female)-were placed in a 4-ha pen. Sexual behaviour was first observed in both stallions in January 1991. Normally the mating season for this species would be in May-June (Geptner et al., 1961). By mid-1991 the two stallions were aggressive towards each other, breaking down the fences of the pens to fight. As a result of this, it was decided to isolate one of the males (L11) in a reinforced 0.2-ha pen, keeping it in reserve for breeding purposes. In August 1992 the other five horses were set free in the main enclosure. Two of the horses had been at the Centre for 33 months and three for 20 months by the time they were released.

\section{Methods}

\section{Observations of area use, breeding behaviour and} social interactions

The observations of movements and the use of the home ranges, and interactions between groups of animals (kulans and horses as well as, later, different groups of horses) were carried out by different observers at different times between 1987 and 1997. V.E.F 


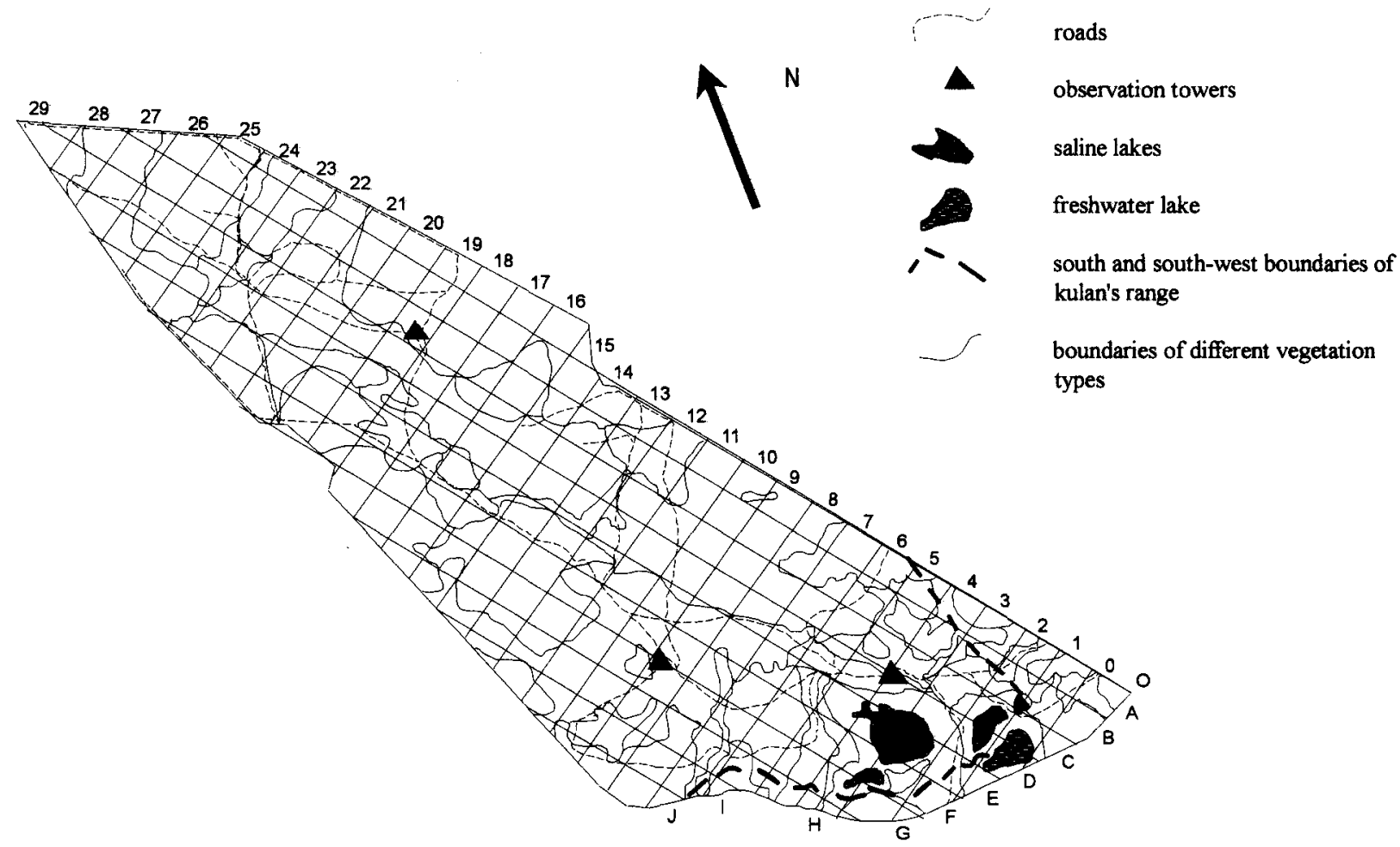

Fig. 2 The release site at Bukhara Breeding Centre showing the main physical features including the observation towers and recording grid

and O.B.P. started observations in 1987 in collaboration with N.V.S. and the Uzbekistan authorities. In 1990 the dissolution of the USSR resulted in fieldwork being blocked for the Russian members of the team, but V.U.D., one of the staff at the Centre, continued to carry out research on Przewalski's horse adaptations until 1992, after which financial support was no longer available. He continued this work in his spare time until leaving the Centre. Other Centre staff continued to record the positions and movements of the horses opportunistically, while carrying out other research or engaged in other duties. O.B.P. and A.J.S. were able to resume fieldwork in May 1993.

Three 20-m-high observation towers were built especially for recording the ungulates' movements (Fig. 2). Other observations were made from vehicles, using the roads through the Centre (Fig. 2), and on foot to check areas obscured by bushes. Each survey always included observations from tower F9, which gave a clear view (using binoculars) of the main enclosure up to grid squares A14-F18, and allowed identification of individual animals as far away as grid squares $\mathrm{A}-\mathrm{J}$ and 9-10 (Fig. 2).

Between May and July 1994, and May and July 1995, G.F. recorded the positions of the horses twice daily (morning and evening). Between November 1995 and
May 1997 the positions were noted at least once a week from roads as far as tower B19 (B. Bahloul and N.V.S). All the data collected were mapped.

\section{Observations of activity patterns}

Activity patterns were recorded individually for the horses, both in the period of adaptation in the 4- and 6-ha pens, and in the main enclosure. Observations were carried out for entire 24-h periods and for the main periods of diurnal activity, and the times spent in various activities were recorded. Activities included: grazing, eating mixed fodder, resting, social contacts, comfort behaviour (self-grooming, rolling, scratching, rubbing), travelling, orientating reaction (vigilance, standing watching, turning the head, smelling the wind, etc.), drinking, territorial marking, and other behaviour. This paper presents the data on the activity of the dominant stallion, M19, in June 1991 (in the 4-ha pen) and in June 1993 (in the main enclosure) during the hours of regular observations $(07.00-10.00 \mathrm{~h}, 17.00-$ $20.00 \mathrm{~h}$ and $12.00-02.00 \mathrm{~h}) ; 100 \mathrm{~h}$ of activity are analysed here.

\section{Analysis of food preferences}

Two analyses of food preferences were carried out: the 
first when the horses were in two groups in the 4- and 6-ha pens in 1991-92; and a subsequent set of analyses when the horses had been released into the main enclosure.

In the first analysis (carried out by V.U.D.), portions of food were supplied to each group of horses at $06.00-07.00 \mathrm{~h}$ and again at $17.00-18.00 \mathrm{~h}$. Any food that remained from a previous meal was removed. The component species of each portion were weighed separately before and after the horses had eaten to determine which species the horses preferred. Control portions of each species were kept in the same conditions for the same periods of time and were weighed at the beginning and end of each period to determine weight changes attributable to exposure to air.

In the second set of analyses in the main enclosure, a method termed 'simultaneous pasturing' was used. An observer positioned about 3-5 $\mathrm{m}$ away from the horses (sometimes closer but never more than $10 \mathrm{~m}$ away) recorded which plants were eaten. The observer used scissors to cut equivalent amounts of each species eaten by an individual horse and stored the samples in a plastic bag to prevent drying. Later the different species of plants were separated and the fresh weight of each determined. These observations were carried out regularly for periods of $0.5-2 \mathrm{~h}$, depending on how long the horse grazed, for different individuals of the group in different types of vegetation. In this paper we present the results of $107 \mathrm{~h}$ of simultaneous pasturing collected by V.U.D. and N.V.S between August 1992 and May 1993.

\section{Results}

Area use, breeding behaviour and social interactions

Area use

After being released into the main enclosure, the horses stayed in the southern portion, using an area of $2.5 \times$ $3 \mathrm{~km}$ and returning to the familiar surroundings of the pens from time to time (Fig. 3A). Within a year they were using the entire southern portion of the enclosure as their home range $(5 \times 5 \mathrm{~km}$; Fig. $3 \mathrm{~B})$, favouring certain places for grazing and for resting $(A B, 3-5)$ in the heat of the day. When subadult males were pushed out of the group (see below), they attempted to stay within the main range of the group (Fig. $3 \mathrm{C}$ ) but then left for the northern portion, passing through the home range of the main group only to visit the watering places (Fig. 3D).

\section{Breeding behaviour}

Neither stallion (M19 and L11) exhibited sexual be- haviour until January 1991, after they had been at Bukhara for 14 months and 1 month, respectively. All four mares foaled between January and July 1992 after a gestation period of 11-11.5 months (Boyd \& Houpt, 1994), the absence of a single breeding season reflecting their captive origin. Only the two foals born in April and May (B2, a male, and B3, a female) survived. The three oldest mares foaled again in 1994 but the mother (L5) of B3 did not. All the mares bore foals in May-July 1995. One 1995 foal died at the age of 3 days and was found to have an undeveloped left kidney. One mare (M26) foaled again in July 1996, achieving three successful foalings at yearly intervals. In 1997 three of the mares foaled successfully (Table 1).

\section{Social interactions within the group}

The stallion M19 was both the dominant stallion and the leader of the group from the start, although forms of social interaction changed over time. M19 did not display typical territorial behaviour at the edges of the home range of the group but when it approached the pen where stallion L11 was kept as a reserve animal, it defecated around the perimeter of the pen to mark its territory. The stallions displayed typical aggressive behaviour from 1992 onwards. The isolated stallion (L11) developed problems with its hooves because the pen was too small for adequate movement, although gravel had been laid down to give an abrasive surface. This stallion was moved to a larger pen but the fence was weaker and the stallion M19 broke down the fence and killed L11.

The first male (B2) born at Bukhara (sired by L11), was killed at the age of 1 year by the dominant stallion M19 in 1993, when the mares came into oestrus. The first female (B3) stayed with its mother and was observed to suckle occasionally until September 1993. When the mother (L5) of B3 came into oestrus in 1994, it pushed B3 away from the group; B3 tried to join the group of kulans in the north of the enclosure and then escaped from the Centre by breaking the fence. It then tried to join a domestic horse outside the Centre and was killed by a shepherd.

In 1995 1-year-old males were initially pushed out of the group by their mothers just after foaling. Each mare left the group some hours before foaling, followed by its son. Each mare stayed $1.5-2 \mathrm{~km}$ from the group for 3-4 days after foaling, being aggressive to the older foal, especially when it tried to suckle. Later the mares joined the main group, keeping their older foals at a distance, but only one mare (L58) continued to be aggressive towards its older foal (B7).

The stallion M19 showed dominant but not aggressive behaviour towards B5 and B7 (the two young males) but was aggressive towards B6 (male) in the 

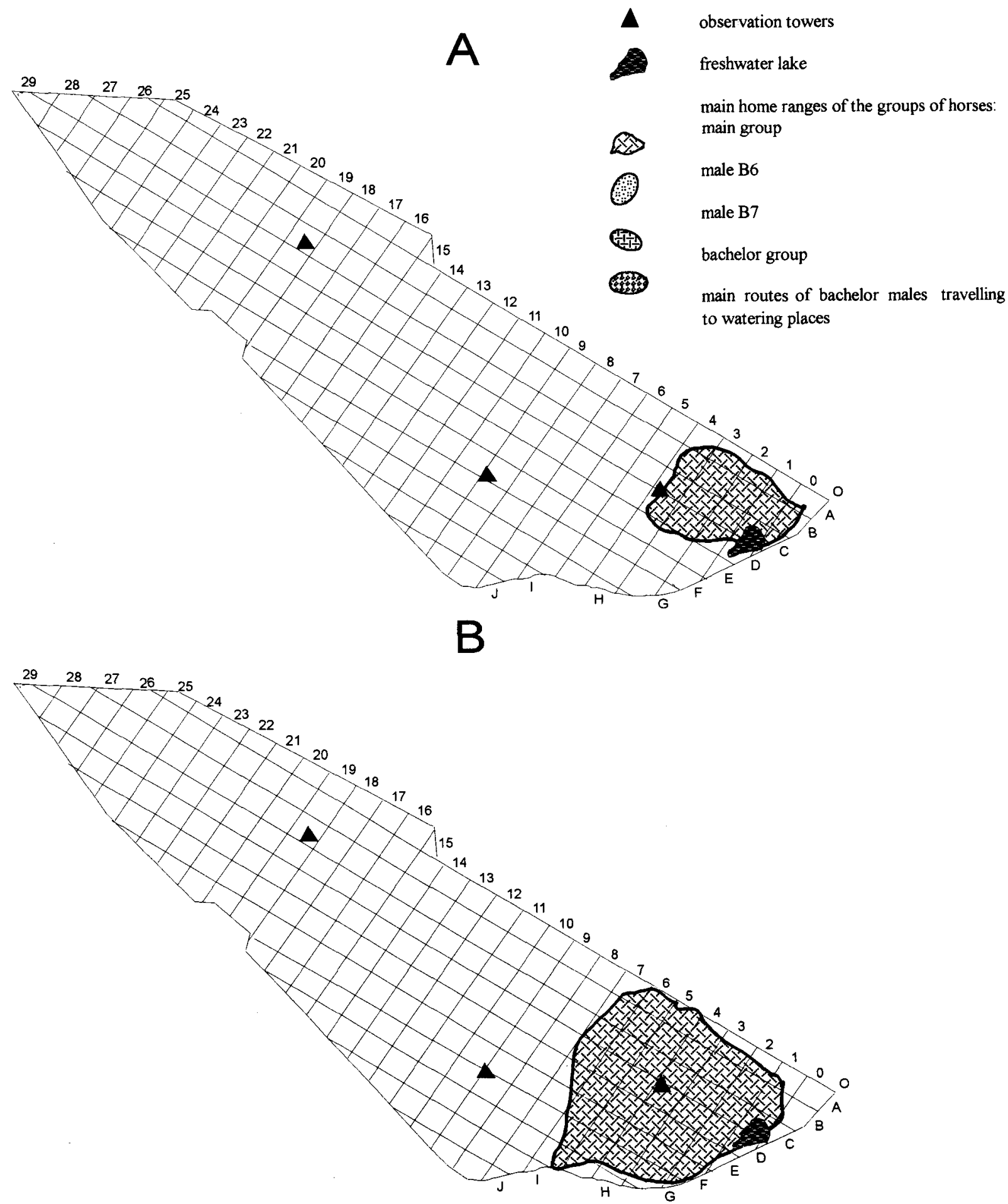

Fig. 3 Usage of the area by Przewalski's horses at Bukhara Breeding Centre. A, September 1991-May 1992; B, 1993-1994; C, June-September 1995; D, September-November 1997; A-J, 0-29, map grid.

same period; $\mathrm{B} 6$ and $\mathrm{B} 7$ then left the main group and stayed on the edges of the home range (Fig. $3 \mathrm{C}$ ), while B5 managed to stay with the main group. The process of subdivision of the group continued for 6 months, with the subadults trying to return to the group, then leaving individually. Eventually B6 and B7 formed a bachelor group with its own home range.

During 1996 the new subadults continued to stay 

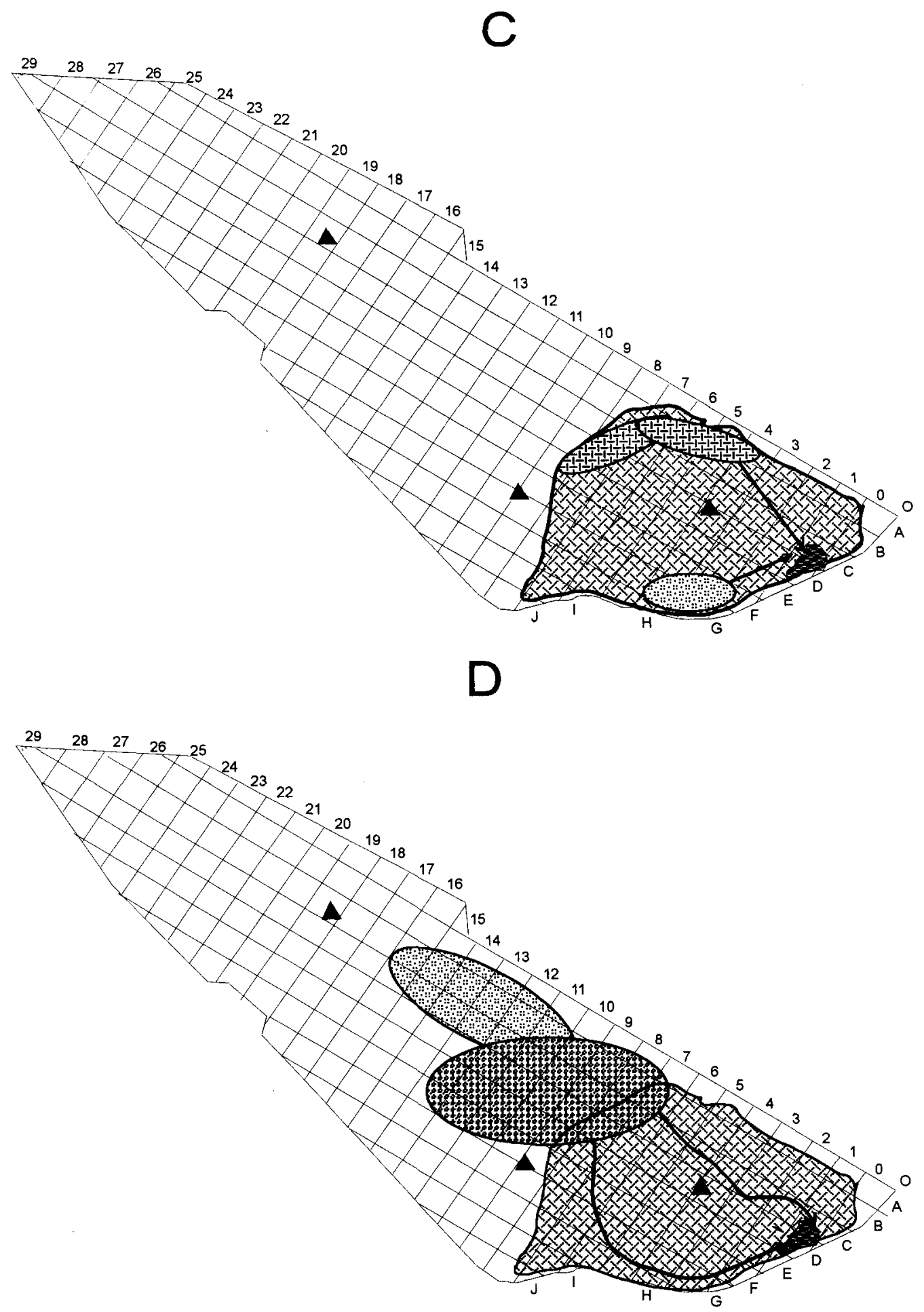

Fig. 3 (Continued)

with the group; only M26 foaled that year and, as in the previous year, was not aggressive to the older son. The rest of the mares maintained close contact with their young even during oestrus and the stallion was not aggressive. In summer-autumn 1997 the young males B9 and B10 and the female B11 (all 2-year-olds) left the main group and joined the bachelor group. This caused conflict between B6 and B7 within the bachelor group, 

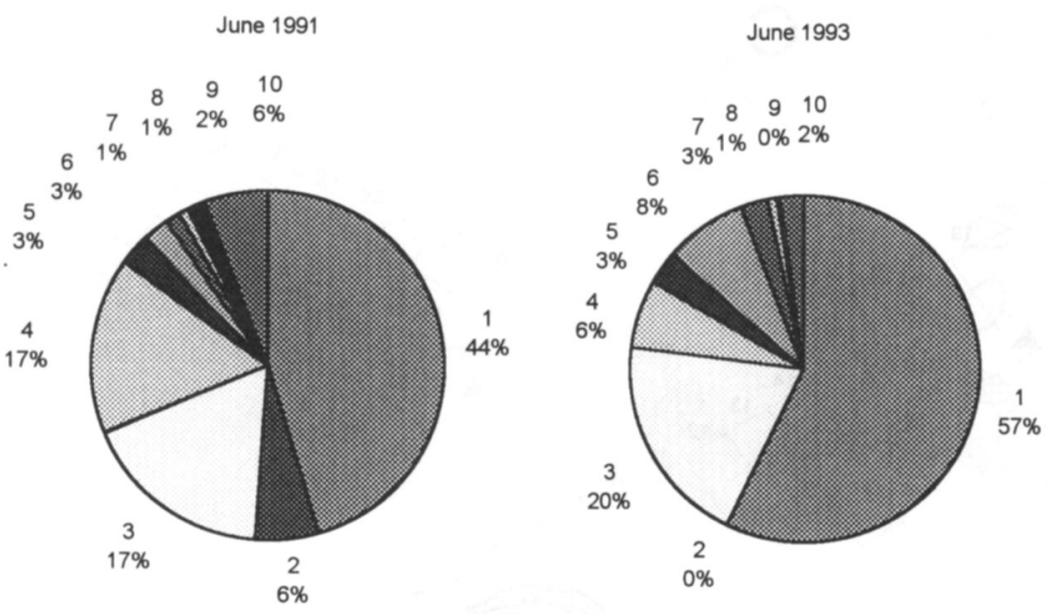

Fig. 4 Comparative daily activity of the stallion M19. 1, grazing; 2, eating mixed fodder; 3, resting; 4, social contacts; 5 , comfort behaviour (self-grooming, rolling, scratching, rubbing); 6 , travelling; 7 , orientating reaction (vigilance, standing watching, turning the head, smelling the wind, etc.); 8, drinking; 9, marking territory; 10 , other forms of activity. which resulted in $B 6$ being expelled and establishing an individual home range further north (Fig. 3D). There were also conflicts between B7 and the stallion M19, who tried to regain the female B11, which resulted in the establishment eventually of two groups with separate home ranges.

To summarize, the situation at the end of 1997 was that the main group comprised: M19 (the stallion); M17, M26, L5, L58 (the four original mares); B12 (a subadult female); B13 and B15 (juvenile males); and B14 (a juvenile female). The other group comprised: $B 7$ (the stallion); B11 (a 2-year-old female); and B9 and B10 (2-year-old males). The stallion $\mathrm{B} 6$ remained alone.

\section{Interaction with other ungulate species}

The study showed that there were no changes in goitred gazelle distribution, population density or habitat use as a result of the introduction of Przewalski's horses. Horses and gazelles formed mixed grazing groups, with recorded distances between individual animals being as little as $2-3 \mathrm{~m}$.

Special attention was given to interactions between kulans and horses. At first the interspecific distances between the main breeding groups of kulans and horses were usually $2-3 \mathrm{~km}$ or more. Kulans and horses used the same grazing areas and watering places but never simultaneously. In the third year after the horses had been introduced into the main enclosure, kulans and horses were recorded at a distance of $500 \mathrm{~m}$ from each other, with no signs of aggressive behaviour. Lone kulans sometimes approached to within $<200 \mathrm{~m}$ of the main group of horses when they were forced to do so under certain conditions, such as when they fled from a vehicle. (The horses were not afraid of vehicles or people but kulans were because vehicles were used in the culling operations for kulans.) When a kulan approached horses, the dominant stallion stood be- tween the mares and the kulan, waiting for the kulan to pass, but never attacked or followed it.

\section{Activity patterns}

The main changes in the daily activity patterns of the stallion M19, after 2 years of semi-wild life (Fig. 4), was in the increase in foraging and travelling times, with less time spent in social interactions, reflecting the more stable composition of the group. In 1995 and 1996, the time budgets of individual horses at different seasons were analysed. Whatever the season, grazing formed around 60 per cent of daily activity, resting occupied 20-25 per cent of the day, 12-15 per cent of the time was spent travelling, and other forms of activity occupied 4-5 per cent of the time.

\section{Use of water}

An unlimited supply of water was provided when the horses were in the small pens and during the first month after release into the main enclosure. At first each horse drank $40-50 \mathrm{~L} /$ day but after 1 year drank only 8-12 L, even in the hottest season. In the main enclosure they used lake water, preferring a salinity of $<7 \mathrm{~g} / \mathrm{L}$ (gazelles and kulans use water of up to $17 \mathrm{~g} / \mathrm{L}$ salinity; Pereladova et al., 1997). Horses were observed to drink usually at dawn and after sunset, while in the middle of the day they rested in open areas $3-5 \mathrm{~km}$ away from the lakes.

\section{Analysis of food preferences}

While kept in the small pens, all the horses were fed with mixed fodder: hay made from desert plants, dried lucerne and, occasionally, vegetables. By the end of the first year the diet offered consisted almost entirely of 
Table 2 The main plants used by Przewalski's horses at Bukhara Breeding Centre

\begin{tabular}{|c|c|c|c|c|}
\hline Plant species & Spring & Summer & Autumn & Winter \\
\hline \multicolumn{5}{|l|}{ Gramineae (Poaceae) } \\
\hline 1. Aeluropus litoralis & + & + & + & + \\
\hline 2. Hordeum leporinum & + & + & + & + \\
\hline 3. Anista tectorum & + & + & + & + \\
\hline 4. Bromus dantoniae & + & + & + & + \\
\hline 6. Eremopyrum cristatum & + & + & + & + \\
\hline 7. Calamagrostis sp. & + & + & - & - \\
\hline 8. Phragmites communis & + & + & + & + \\
\hline 9. Cynodon dactylon & + & + & + & + \\
\hline 10. Poa bulbosa & + & + & - & - \\
\hline \multicolumn{5}{|l|}{ Chenopodiaceae } \\
\hline 11. Halostachys belangeriana & + & - & + & + \\
\hline 13. Haloxylon aphyllum & - & + & + & + \\
\hline 14. Chenopodium album & - & + & - & - \\
\hline 15. Salsola spp. & + & - & + & + \\
\hline 16. Halonemum strobilaceae & - & - & + & + \\
\hline 17. Aellenia subaphylla & + & - & + & + \\
\hline \multicolumn{5}{|l|}{ Compositae } \\
\hline 18. Amberboa turanica & + & - & - & - \\
\hline 19. Epilasia hemilasia & + & + & - & - \\
\hline 20. Epilasia mirabilis & + & - & - & - \\
\hline 21. Cousinia dichotonia & - & - & + & + \\
\hline 22. Lactuca tatarica & + & - & - & - \\
\hline 23. Karelinia caspica & - & - & + & + \\
\hline 24. Koelpinia linearis & + & + & - & - \\
\hline \multicolumn{5}{|l|}{ Leguminosae } \\
\hline 27. Medicago sativa & + & + & + & + \\
\hline 28. Smirnowia turkestana & + & + & + & + \\
\hline \multicolumn{5}{|l|}{ Polygonaceae } \\
\hline 29. Calligonum caput-medusa & + & - & + & + \\
\hline 30. Calligonum microcarpum & + & - & + & + \\
\hline \multicolumn{5}{|l|}{ Zygophyllaceae } \\
\hline 31. Zygophyllum macrophyllum & - & - & + & + \\
\hline 32. Zygophyllum eichwaldii & - & - & + & + \\
\hline \multicolumn{5}{|l|}{ Liliaceae } \\
\hline 33. Gagea lutea & + & - & + & + \\
\hline 34. Tulipa sp. & + & - & - & - \\
\hline \multicolumn{5}{|l|}{ Convolvulaceae } \\
\hline 35. Convolvulus hamada & - & + & - & - \\
\hline \multicolumn{5}{|l|}{ Ranunculaceae } \\
\hline 36. Delphinium rugulosum & + & + & - & - \\
\hline \multicolumn{5}{|l|}{ Boraginaceae } \\
\hline 37. Arnebia baldschuanica & + & + & - & - \\
\hline \multicolumn{5}{|l|}{ Caryophyllaceae } \\
\hline 38. Hallosteum spp. & + & - & - & - \\
\hline \multicolumn{5}{|l|}{ Equisetaceae } \\
\hline 39. Equisetum arvense & + & - & - & - \\
\hline \multicolumn{5}{|l|}{ Plumbaginaceae } \\
\hline 40. Limonium otolepus & + & - & + & + \\
\hline \multicolumn{5}{|l|}{ Tamaricaceae } \\
\hline 41. Tamarix sp. & + & - & + & + \\
\hline
\end{tabular}


Table 2 (Continued)

\begin{tabular}{|c|c|c|c|c|}
\hline Plant species & Spring & Summer & Autumn & Winter \\
\hline \multicolumn{5}{|l|}{ Elaeagnaceae } \\
\hline 42. Elaeagnus turcomanica & - & + & + & + \\
\hline \multicolumn{5}{|l|}{ Cyperaceae } \\
\hline 43. Carex physodes & + & + & + & + \\
\hline \multicolumn{5}{|l|}{ Cruciferae } \\
\hline 44. Strigosella spp. & + & + & - & - \\
\hline \multicolumn{5}{|l|}{ Euphorbiaceae } \\
\hline 45. Hondrilla plumosa & - & + & + & + \\
\hline \multicolumn{5}{|l|}{ Papaveraceae } \\
\hline 46. Papaver pavominum & + & - & - & - \\
\hline
\end{tabular}

Species names follow Kamelin \& Takhtadjan (1974) and Tcherepanov (1981).

local hay. When the horses were in the main enclosure they had access to 3 ha of lucerne fields between July and September, after haymaking. Since 1994 they have lived entirely on natural desert vegetation.

From the very start of the experiment, the animals grazed plants that were growing in the pens, even when offered abundant alternative food. They preferred grass species (Graminae), and completely refused any Salsola spp. (Chenopodiaceae). The latter are very important and seasonally preferred food plants for gazelles. As soon as they were released from the pens the horses grazed about 20 plant species; by the following year more than 46 species of the 200 species occurring at Bukhara were recorded as being used (Table 2; Mordonov, 1993). Seasonal preferences are shown in Fig. 5.

Comparing food preferences of gazelles (Mordonov, 1993) and horses revealed that these two species have only 43 per cent of plant species in common, while there is an 87 per cent overlap in food species for kulans (Solomatin, 1973) and horses.

\section{Discussion}

The experiment was designed to answer some of the main questions concerning the restoration of Przewalski's horse to the wild. We needed to know if it would be possible for zoo-bred animals to adapt to conditions in the wild and, specifically, to desert habitats. We also needed to discover the consequences of interspecific interaction between species of ungulates in the same area.

There are problems with the restoration of Przewalski's horse within optimum steppe habitat because most of the areas have been converted to agriculture or to pastures for domestic horses, which poses a serious threat of hybridization. As a result of these problems we suggested some desert areas as suitable for establishment of a semi-wild population of Przewalski's horses (Flint et al., 1990, 1991). The historical range of the species included deserts but the horses disappeared from these areas. The reasons for this were suggested as being either because of direct anthropogenic pressures (competition with domestic stock and hunting) or because the horse could not survive in deserts alone
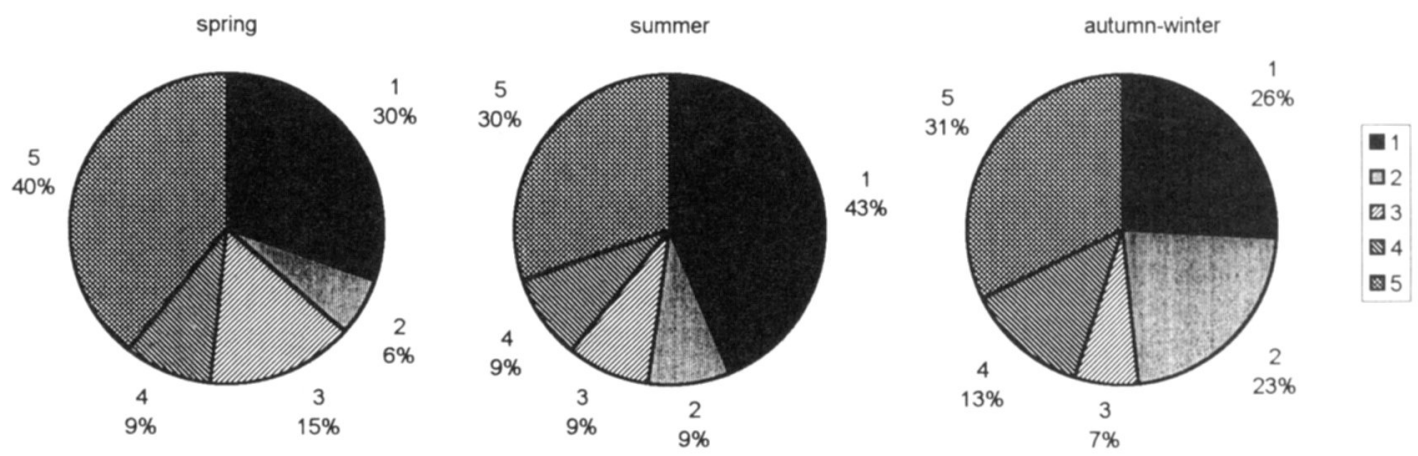

Fig. 5 Quantitative seasonal food preferences of Przewalski's horses at Bukhara Breeding Centre. 1, Graminae (Poaceae); 2, Chenopodiaceae; 3, Compositae (Asteracea); 4, Leguminaceae (Fabaceae); 5 , other families. 
and had been forced there from its preferred habitats by human activity.

The introduced captive-bred horses changed dramatically in the first year while they were still in small pens. They became used to natural vegetation in their diet and to the salinity of the water. Changes in behaviour were observed, especially social and sexual behaviour, as well as bodily changes, such as moulting (Flint et al., 1989). The results of our experiment indicate that zoobred horses can adapt to desert conditions and suggest that the causes of extinction in the wild were a direct result of human activities rather than desert habitats being unsuitable. The horses have been living for several years now without additional food, both in favourable and very dry years. They spend little time near watering places, choosing open areas $3-5 \mathrm{~km}$ away from lakes as favoured resting places in the heat of the day.

Foaling is now seasonal, which is typical of wild equids. Moreover M26, the youngest mare, foaled in four consecutive years from 1994 to 1997, whereas L58, the eldest, bred successfully in 1994, 1995 and 1997. This indicates that the horses are not simply adapted to desert conditions but that they are in good condition themselves (Duncan, 1992b).

In 1991, foraging times were very similar to those found in other studies carried out on Przewalski's horses in different types of enclosures: feeding by males-47.5 per cent (in a yard), 50.6 per cent (in pasture; Boyd \& Houpt, 1994). Since 1993 the daily activities of the horses have varied seasonally and individually (Pereladova et al., unpublished data), but generally are now similar to those of adult wild horses in the Camargue. Foraging times vary in wild horses from 53.6 to 63.6 per cent of total activity time in different seasons (Duncan, 1992b). Social behaviour of horses in the group gradually became more and more varied both as a result of the adaptation of animals to semi-wild conditions and the growth of the group.

The presence of other ungulate species appears not to be an obstacle for the establishment of a free-ranging population of Przewalski's horses: indeed, it could be beneficial for the development of biodiversity because of the different food preferences (Mordonov, 1993). There were no interspecific conflicts, even between the closely related kulan and Przewalski's horse. No attempts to create an interspecific group were observed, although the probability of such events had been partly expected, especially when the first young horses were expelled from the main breeding group. Neither aggressiveness nor territorial behaviour resulted from interspecific interactions. Such behaviour was recorded only between horses (individuals and, later, groups), as it was for kulans. The development of the Przewalski's horse groups followed a similar pattern to that previously recorded for kulans. During the early years of breeding in the Centre, infant mortality was high as a result of aggressive behaviour by the stallion and the group grew slowly. When three newborn males survived 1 year, two of them formed a bachelor group when they were about 1 year old. Since then the young have not been killed by the dominant stallion because they could avoid aggressive behaviour by joining the bachelor group. This was also true for kulan. Between 1979 and 1982 only one newborn male survived each year because of aggression from older male kulans. In 1983 a bachelor group formed and rapid growth of the population followed.

\section{Conclusions}

The main conclusions resulting from the 7-year study are listed below.

- Desert conditions are suitable for Przewalski's horses; animals from zoos are able to adapt to extreme conditions and the natural seasonal reproductive cycle is restored within 1 year.

- Steppe vegetation is not necessary for the horses; they maintain good condition using natural desert vegetation, and foal regularly and successfully.

- In order to avoid aggression between males, resulting in the death of young animals, it is recommended that both harem and bachelor groups of young males are introduced from the start of reintroduction into a new area.

\section{Acknowledgements}

We are very grateful to the Ministry of Ecology of Uzbekistan, 'Gobiscontrole'-Mr A. K. Atadjanov, and the Directors of the Bukhara Breeding Centre, for enabling our work to take place. We are also grateful to the Director of Moscow Zoo, V. V. Spitsin, and his staff, as well as to Leningrad Zoo, for providing the initial animals for the study. The observations of the horses, which were interrupted in 1990 because of political and economic problems, were renewed in May 1993 thanks to collaboration with CNRS, France, on PICS 266. In March 1995-August 1996 the work was supported by a personal grant from the MacArthur Foundation. We are very grateful to $\mathrm{Dr} B$. Mordonov, N. Marmosinskaya and K. K. Bahloul, whose records of the positions of the groups of animals helped to create a joint picture of spatial distribution. 


\section{References}

Bouman, J.G. \& Bos, H. (1979) Two symptoms of inbreeding depression in Przewalski's horses living in captivity. In Genetics and Hereditary Diseases of Przewalski's Horse (eds L. E. M. De Boer, I. Bouman and J. Bouman), pp. 111-117. Foundation for Przewalski's Horse, Rotterdam.

Bouman, J. \& Bouman, I. (1988) Captive breeding of Przewalski's horse survival of its Przewalski's-like descendants or the conservation of Przewalski's horse? In International Symposium: Gefahren fur die Arterhaltung durch Gefargenschaft.

Boyd, L. \& Houpt, K.A. (1994) Activity patterns. In Przewalski's Horse-the History and the Biology of the Endangered Species (eds L. Boyd and K. A. Houpt), pp. 195-228. State University of New York Press, Albany.

Duncan, P. (ed.) (1992a) Zebras, Asses, and Horses: An Action Plan for the Conservation of Wild Equids. IUCN/SSC/WWF, Gland, Switzerland.

Duncan, P. (1992b) Horses and Grasses: the Nutritional Ecology of Equids and their Impact on the Camargue. Ecological Studies, 87. Springer-Verlag, New York.

Flint, V.E., Soldatova, N.V. \& Spitsin, V.V. (1989) Preliminary results of the experiment on semi-wild maintenance of Przewalski's horse in arid conditions. In Ecology, Morphology, Usage and Conservation of Wild Ungulates, vol. 2 (ed. T. B. Sablina), pp. 288-289. Abstracts of an All-Union Conference on Ungulates, Moscow [in Russian].

Flint, V.E., Pereladova, O.B. \& Mirutenko, M.W. (1991) Stand und Probleme der Wiedereinburgerung von Przewalskipferden in der USSR. Internationales Symposium zur Erhaltung des Przewalsipferdes, pp. 191-198. Zoologischer Garten, Leipzig.

Flint, V.E., Pereladova, O.B., Mirutenko, M.V. \& Jirnov, L.V. (1990) Experimental programme on free Przewalski's horse population creation in Kazakhstan-Middle Asian region. In Rare and Endangered Species of Mammals of the USSR (ed. V. E. Sokolov), pp. 98-113. Nauka (Science), Moscow [in Russian]

Geptner, V.G., Nasimovitch, A.A. \& Bannikov, A.G. (1961) Mammals of the Soviet Union. Ungulates, vol. 1. High School, Moscow [in Russian].

Kamelin, R.V. \& Takhtadjan, A.L. (eds) (1974) Determinant of Plants of Central Asia, vol. 2. Fan, Tashkent [in Russian].

Krever, V., Pereladova, O., Williams, M. \& Jungius, H. (eds) (1998) Biodiversity Conservation in Central Asia. An Analysis of Biodiversity and Current Threats and Initial Investment Portfolio. RPO WWF, Moscow.

Miller, R. (1988) Review of investigations of wild horses, dealing with Przewalski's horse restoration. In The Przewalski's Horse and its Restoration in Nature in Mongolia. Proceedings of FAO/UNEP Meeting, Moscow, 1985 (eds V. E. Sokolov and V. N. Orlov), pp. 191-199. CMP GKNT, Moscow [in Russian].

Mordonov, B.K. (1993) Goitred gazelle influence over the vegetation of deserts. PhD thesis, VNII priroda, Moscow [in Russian].
Nouls, G.M. (1988) Methods of Przewalski's horse restoration. In The Przewalski's Horse and its Restoration in Nature in Mongolia, Proceedings of FAO/UNEP Meeting, Moscow, 1985 (eds V. E. Sokolov and V. N. Orlov), pp. 191-199. CMP GKNT, Moscow [in Russian]

Pereladova, O.B., Karlsen, A.G. \& Sempéré, A.J. (1997) Quality of water in the watering places of ungulates in Bukhara Breeding Centre (Uzbekistan). In Rare Mammals of Russia and Bordering Areas, Abstracts of International Conference, 9-11 April 1997, Moscow, p. 69 [in Russian].

Peredalova, O.B., Bahloul, K. Sempéré, A.J., Soldatova, N.V., Schadilov, U.M. \& Prisiadznuk, V.E. (1998) Influence of environmental factors on a population of goitred gazelles (Gazella subgutturosa subgutturosa Güldenstaedt, 1780) in semi-wild conditions in an arid environment: a preliminary study. Journal of Arid Environments, 39, 577-591.

Ryder, O. (1988) Genetical analysis of Przewalski's horse in captivity. In The Przewalski's Horse and its Restoration in Nature in Mongolia. Proceedings of a FAO/UNEP Meeting, Moscow, 1985 (eds V. E. Sokolov and V. N. Orlov), pp. 50-103. CMP GKNT, Moscow [in Russian].

Shenbrot, G.I. (1987) The productivity of pastures and the role of rodents as food concurrents of gazelles. In Regional Aspects of Gazelle Biology, pp. 105-113. VINITI, 2745-B87, Moscow [in Russian].

Solomatin, A.O. (1973) Kulan. Nauka (Science), Moscow [in Russian].

Tcherepanov, S.K. (1981) Vascular Plants of the USSR. Nauka (Science), Leningrad.

Volf, J. (1981) Lebensauer de Przewalski's-Wildpferde (Equus przewalski Polf, 1881) in Gefangenschaft. Zoologische Garten, 51(56), 385-387.

\section{Biosketches}

Olga Pereladova $\mathrm{PhD}$ is a senior researcher, carring out field investigations in ecology, behaviour, acoustic communication, conservation and restoration of rare species of ungulates within FSU. She is WWF project leader for Central Asia and large herbivores.

Dr Antoine Sempéré specializes in the physiology of deer. He has demonstrated the evidence of endogenous cycles in roe deer and the role of photoperiod in the adjustment of the sexual cycle. Recently, he has developed new research in adaptive reproduction of ungulates in extreme environments. He is the director of CNRS office in Moscow for NIS.

Professor V. Flint is a very well known ornithologist and the leading Russian scientist in rare species conservation and restoration, working with birds of prey, rare cranes, etc. He has received the Global 500 award and the Golden Ark Order and the Audubon medal. The Przewalski horse experiment was initiated by Professor Flint in 1987. 